\title{
Mungkinkah Kalimantan Timur Mencapai Kemandirian Pangan di Tahun 2025?*
}

\author{
Could East Kalimantan Achieve Food Self Sufficiency in 2025?
}

\author{
Adi Supriadi \\ Program Studi Pengelolaan Lingkungan, Politeknik Pertanian Negeri Samarinda, Indonesia. \\ Corresponding Author: adisupriadi.politani@gmail.com
}

*Sebagian isi dalam artikel ini pernah disampaikan dalam KLHS RPJMD Kalimantan Timur 2018-2023

\begin{abstract}
Abstrak
Kemampuan produksi beras Kalimantan Timur hanya cukup untuk 1.316 .433 orang, jauh dari memenuhi kebutuhan seluruh Kaltim sebanyak 3.721.400 orang. Untuk itu, diperlukan berbagai pemikiran dan kajian terkait strategi kemandirian pangan di Kalimantan Timur, terutama dengan rencana pemindahan ibu kota negara. Kajian ini dilakukan melalui analisis mendalam terhadap berbagai dokumen pembangunan di Kalimantan Timur dan berbagai literatur lain yang relevan. Berbagai kecenderungan ke depan seperti jumlah penduduk, pola konsumsi dan lain-lain diambil dari sumber resmi seperti biro statistik pusat dan dokumen milik organisasi perangkat daerah (OPD) terkini, serta dengan perhitungan menggunakan data yang tersedia. Hasil kajian mendalam terhadap berbagai dokumen tersebut menunjukkan bahwa kemandirian pangan dapat dicapai di Kaltim jika dalam 5 tahun ke depan mampu meningkatkan produksi padi sebesar $10 \%$ per tahun atau meningkat sekitar $77 \%$ dalam 5 tahun dan mengurangi tingkat konsumsi beras menjadi $70 \mathrm{~kg} / \mathrm{kapita} / \mathrm{tahun}$. Untuk mendukung terwujudnya tujuan tersebut perlu dilakukan upaya untuk menjamin ketersediaan, kesiapan dan keamanan lahan pertanian; meningkatkan produktivitas lahan pertanian dan mengurangi tingkat konsumsi beras per kapita.
\end{abstract}

Kata Kunci: Kemandirian Pangan, Kalimantan Timur, Produksi Padi

\begin{abstract}
East Kalimantan's rice production capacity is only sufficient for 1,316,433 people, far from meeting the needs of the entire East Kalimantan of 3,721,400 people. For this reason, various ideas and studies are needed related to the strategy of food self-sufficiency in East Kalimantan, especially with the plan to move the country's capital. This study was carried out through in-depth analysis of various development documents in East Kalimantan and various other relevant literatures. Various future trends such as population size, consumption patterns and others are taken from official sources such as the central statistical bureau and documents owned by the latest regional apparatus organizations (OPD), as well as by calculations using available data. The results of an in-depth study of these various documents show that food independence can be achieved in East Kalimantan if in the next 5 years it is able to increase rice production by $10 \%$ per year or increase by around $77 \%$ in 5 years and reduce the level of rice consumption to $70 \mathrm{~kg} /$ capita / year. To support the realization of these goals, efforts must be made to ensure the availability, readiness and safety of agricultural land; increase the productivity of agricultural land and reduce the level of rice consumption per capita.
\end{abstract}

Keywords: Food Self Sufficiency, East Kalimantan, Rice Production

\section{PENDAHULUAN}

Pemerintah Indonesia telah menerbitkan Undang-Undang Nomor 18 Tahun 2012 tentang Pangan dan Perpres Nomor 22 Tahun 2019 tentang Kebijakan Percepatan Penganekaragaman Konsumsi Pangan Berbasis Sumber Daya Lokal. Kedua kebijakan tersebut mengamanatkan ketahanan pangan yang dibangun harus berbasis pada kemandirian pangan dengan mendorong produksi pangan yang beranekaragam dengan memanfaatkan sumberdaya lokal. Dengan demikian, ketahanan pangan seharusnya dimaknai sebagai kemandirian pangan yang berbasis pada pemanfaatan lahan setempat dan sumberdaya manusia (petani) lokal.

Pemahaman dari dua kebijakan tersebut seharusnya mampu mendorong pemerintah Kalimantan Timur untuk keluar dari ketergantungan terhadap bahan pangan dari daerah lain, atau setidaknya mengurangi ketergantungannya, tetapi yang terjadi pada 
2 tahun terakhir justru sebaliknya. Data BPS Kaltim (2020) menyatakan pada tahun 2019 Kalimantan Timur menghasilkan 253.818,37 ton padi $(146.887,61$ ton beras), lebih kecil dari tahun sebelumnya yang mencapai $262.773,88$ ton atau $152.059,91$ ton beras. Jika melihat data luas panen, penurunan tersebut lebih disebabkan oleh penurunan produktifitas ketimbang penurunan luas panen. Data luas panen menunjukkan pada tahun 2018 seluas 64.961,16 hektar dan 69.707,75 hektar pada 2019.

Dengan mengacu jumlah konsumsi beras perkapita sebesar $111,58 \mathrm{~kg}$ pertahun (BPS, 2019), maka kemampuan produksi beras Kalimantan Timur hanya cukup untuk 1.316.433 jiwa, jauh dari mencukupi kebutuhan seluruh masyarakat Kalimantan Timur yang berjumlah 3.721 .400 jiwa. Untuk itu diperlukan berbagai gagasan dan kajian terkait strategi kemandirian pangan di Kalimantan Timur, apalagi dengan rencana kepindahan ibukota negara. Secara khusus penelitian ini bertujuan untuk untuk menganalisa apakah kemandirian pangan di Kaltim akan dapat terwujud dalam kurun waktu 5 tahun mendatang? Hasil analisa pada penelitian ini diharapkan dapat dijadikan bahan pertimbangan untuk menyusun strategi dalam upaya mewujudkan kemandirian pangan di Kaltim.

\section{METODE PENELITIAN}

Kajian ini dilakukan melalui analisa mendalam berbagai dokumen pembangunan di Kalimantan Timur dan berbagai literatur lain yang relevan. Berbagai kecenderungan masa depan seperti jumlah penduduk, pola konsumsi dan lain-lain diambil dari sumbersumber resmi seperti biro pusat statistic dan dokumen yang dimiliki oleh organisasi perangkat daerah (OPD) terbaru yang bisa didapatkan, serta dengan perhitungan dengan menggunakan data yang tersedia.

Pada artikel ini analisis kemandirian pangan hanya pada satu komoditi pangan yaitu padi/beras, karena dari berbagai jenis komoditi pangan, ketersediaan data produksi dan konsumsi padi/beras lebih memadai untuk dianalisis lebih jauh. Selain itu, juga karena beberapa asumsi sebagai berikut:

1. Beras merupakan sumber karbohidrat utama bagi masyarakat Kalimantan Timur
2. Petani yang menanam padi bisa dipastikan juga memiliki komoditi tanaman pangan yang lain seperti jagung, ubi jalar, ubi kayu, sayuran dan lain-lain, jika lahannya tersedia, atau setidaknya di sekitar rumahnya.

3. Petani yang menanam padi, dan kemudian menanam berbagai jenis tanaman pangan lain akan memiliki kecenderungan untuk memelihara binatang ternak sebagai sumber protein dan juga sebagai tabungan.

Dengan 3 (tiga) asumsi tersebut, peningkatan produksi padi harapannya diikuti oleh peningkatan produksi jagung, ubi jalar, sayuran dan bahan pangan yang lain serta sumber protein hewani dari binatang ternak termasuk didalamnya ikan air tawar.

\section{HASIL DAN PEMBAHASAN}

Untuk memastikan Kalimantan Timur mencapai kemandirian pangan maka harus dilihat kecenderungan (trend) jumlah produksi dan tingkat konsumsi beras serta pertumbuhan penduduk. Tiga hal tersebut menjadi dasar strategi (scenario) kemandirian pangan bisa dirumuskan, dengan asumsi lahan pertanian tersedia dan siap ditanami. Menyiapkan lahan ini merupakan salah satu tantangan terbesar dalam mencapai kemandirian pangan di Kalimantan Timur karena kondisi tanahnya yang kurang cocok untuk budidaya tanaman semusim, apalagi padi sawah.

Secara luasan Kalimantan Timur memiliki lahan pertanian yang cukup luas. Berdasarkan data dinas tanaman pangan dan hortikultura Kalimantan Timur 2018, luas lahan pertanian kaltim mencapai 9.972.777,4 hektar. Lahan sawah seluas 93.045,5 hektar dan lahan bukan sawah 9.879.730,9 hektar. RPJMD Kaltim 2018-2023 menyebutkan bahwa saat ini terdapat 5.247 ha sawah beririgasi di Kalimantan Timur. Jika Kalimantan Timur dengan teknologi yang tersedia mampu menyiapkan lahan pertanian yang siap tanam, maka kapasitas produksi bisa ditingkatkan dengan berbagai perlakuan. Dengan mengurangi tingkat konsumsi beras dan memperkirakan pertumbuhan penduduk maka kemandirian pangan di Kalimantan Timur sangat mungkin untuk dicapai. 
Tabel 1. Jumlah Produksi dan Konsumsi Beras Kalimantan Timur Tahun 2011 - 2019

\begin{tabular}{cccccccccc}
\hline & $\mathbf{2 0 1 1}$ & $\mathbf{2 0 1 2}$ & $\mathbf{2 0 1 3}$ & $\mathbf{2 0 1 4}$ & $\mathbf{2 0 1 5}$ & $\mathbf{2 0 1 6}$ & $\mathbf{2 0 1 7}$ & $\mathbf{2 0 1 8}^{*}$ & $\mathbf{2 0 1 9}^{*}$ \\
\hline $\begin{array}{c}\text { Produksi beras } \\
\text { (ton) }\end{array}$ & 267,430 & 266,905 & 276,187 & 268,098 & 256,919 & 239,184 & - & 262,773 & 253,818 \\
$\begin{array}{c}\text { Konsumsi beras } \\
\text { (ton) }\end{array}$ & 356,064 & 364,765 & 373,446 & 382,060 & 390,660 & 385,208 & - & - & - \\
$\begin{array}{c}\text { Kekurangan } \\
\text { produksi }\end{array}$ & $\mathbf{8 8 , 6 3 4}$ & $\mathbf{9 7 , 8 6 0}$ & $\mathbf{9 7 , 2 5 9}$ & $\mathbf{1 1 3 , 9 6 2}$ & $\mathbf{1 3 3 , 7 4 1}$ & $\mathbf{1 4 6 , 0 2 4}$ & - & - & - \\
\hline
\end{tabular}

Sumber: Rencana Aksi Daerah Pangan dan Gizi Kalimantan Timur 2018 dan Kalimantan Timur Dalam Angka 2020.

\section{Jumlah produksi dan pola konsumsi beras}

Produksi beras di Kalimantan Timur cenderung tidak mengalami perubahan yang signifikan sepanjang tahun 2011 hingga 2020, sedangkan jumlah konsumsi cenderung naik meskipun terjadi penurunan pada tahun 2016. Berikut adalah kecenderungan produksi dan konsumsi beras Kalimantan Timur 2011 - 2019.

Dari tabel diatas menunjukkan bahwa sejak tahun 2011 tingkat ketergantungan beras Kalimantan Timur terhadap daerah lain semakin tinggi. Dengan mencermati jumlah penduduk pada tahun-tahun tersebut, tingkat konsumsi beras masyarakat Kalimantan Timur masih cukup tinggi, 114 $\mathrm{kg} /$ kapita/tahun pada tahun 2015 dan 110 $\mathrm{kg} /$ kapita/tahun pada 2016. Menurut BPS Kaltim (2020), tingkat konsumsi beras Kalimantan Timur sebesar 111,58 $\mathrm{kg} /$ kapita/tahun, sedangkan data Kementerian Pertanian (2020) rata-rata konsumsi beras sebesar 92,9 kg/kapita/tahun dan target hingga tahun 2024 sebesar 85 $\mathrm{kg} / \mathrm{kapita} /$ tahun.

\section{Proyeksi jumlah penduduk}

Jumlah penduduk Kalimantan Timur pada tahun 2020 sebanyak 3.766.039 jiwa yang terdiri dari 1.961.634 laki-laki dan 1.804.405 perempuan (BPS Kaltim, 2020). Dalam kurun waktu 2010-2020 pertumbuhan penduduk kaltim sebesar 2,13 persen pertahun. Dengan asumsi ibukota negara pindah ke Kalimantan Timur pada 2024 yang mengakibatkan pertambahan penduduk sebesar 1,5 juta jiwa. Berikut adalah gambaran proyeksi jumlah penduduk Kalimantan Timur hingga tahun 2025.

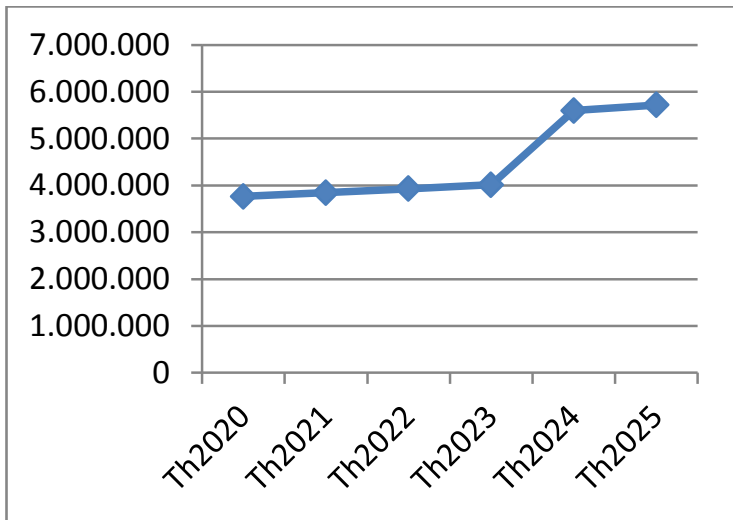

Gambar 1. Proyeksi Jumlah Penduduk Kalimantan Timur

Berdasarkan gambar diatas jumlah penduduk Kalimantan Timur pada 2025 mendekati 6 juta atau lebih tepatnya 5.716.526 jiwa.

\section{Skenario kemandirian pangan}

Skenario kemandirian pangan dirumuskan dengan pendekatan perkiraan produksi beras dan tingkat konsumsi beras perkapita/tahun. Produksi beras diupayakan mengalami peningkatan sepanjang 5 tahun mendatang, yang mana Kalimantan Timur pernah menargetkan kenaikan produksi beras sebesar $20 \%$ pertahun. Merujuk pada target tersebut, terdapat 3 (tiga) skenario kenaikan produksi beras yaitu kenaikan sebesar $5 \%$ pertahun, $10 \%$ pertahun atau $20 \%$ pertahun. Tingkat konsumsi beras diusahakan turun sampai $70 \mathrm{~kg} / \mathrm{kapita} / \mathrm{tahun}$ sebagaimana tingkat konsumsi beras penduduk Thailand. Berikut adalah skenarioskenario tersebut. 
Tabel 2. Skenario Produksi dan Tingkat Konsumsi Beras Kalimantan Timur

\begin{tabular}{lll}
\hline & \multicolumn{1}{c}{ Produksi beras (ton/tahun) } & \multicolumn{1}{c}{$\begin{array}{c}\text { Tingkat konsumsi beras } \\
\text { (kapita/tahun) }\end{array}$} \\
\hline Skenario 1 & Naik 5\% per tahun & $111,58 \mathrm{~kg}$ (Kaltim 2019) \\
Skenario 2 & Naik 10\% per tahun & $85 \mathrm{~kg}$ (target nasional 2024) \\
Skenario 3 & $\begin{array}{l}\text { Naik 20\% per tahun (berdasarkan target } \\
\text { dalam RAD Pangan dan Gizi Kaltim } \\
\text { 2014-2018) }\end{array}$ & \\
\hline
\end{tabular}

Tabel 3. Perkiraan Jumlah Konsumsi dan Produksi Beras Kalimantan Timur s/d Tahun 2025

\begin{tabular}{lcccccc}
\hline & \multicolumn{6}{c}{ Jumlah Konsumsi dan Produksi Beras (ton) } \\
\cline { 2 - 7 } & Th2020 & Th2021 & Th2022 & Th2023 & Th2024 & Th2025 \\
\hline Tingkat konsumsi beras 111.58 kg & 420,215 & 429,165 & 438,306 & 447,642 & 624,547 & 637,850 \\
Tingkat konsumsi beras 85 kg & 320,113 & 326,932 & 333,895 & 341,007 & 475,771 & 485,905 \\
Tingkat konsumsi beras 70 kg & 263,623 & 269,238 & 274,973 & 280,830 & 391,811 & 400,157 \\
Kenaikan produksi beras 5\% & 253,818 & 266,509 & 279,834 & 293,826 & 308,517 & 323,943 \\
Kenaikan produksi beras 10\% & 253,818 & 279,200 & 307,120 & 337,832 & 371,615 & 408,776 \\
Kenaikan produksi beras 20\% & 253,818 & 304,582 & 365,498 & 438,598 & 526,317 & 631,580 \\
\hline
\end{tabular}

Dengan menggunakan 3 skenario peningkatan produksi beras dan 3 skenario penurunan tingkat konsumsi beras tersebut, skenario kemandirian pangan Kalimantan Timur dikembangkan. Mengacu proyeksi jumlah penduduk pada Gambar 1. jumlah konsumsi beras Kalimantan Timur pada 2025 lebih dari 637 ton, jika tingkat konsumsi beras sebesar 111,58 $\mathrm{kg} / \mathrm{kapita/tahun.} \mathrm{Jumlah}$ konsumsi beras sebesar itu tidak akan mampu dipenuhi oleh Kalimantan Timur, meskipun berhasil meningkatkan produksi beras sebesar 20 persen pertahun selama 5 tahun atau sekitar $250 \%$ dalam 5 tahun. Berikut adalah hasil perkiraan jumlah konsumsi dan produksi beras Kalimantan Timur.

Skenario paling realistis dari tabel diatas, kemandirian pangan bisa dicapai pada tahun 2025 jika Kalimantan Timur mampu meningkatkan kemampuan produksi beras $10 \%$ pertahun atau sekitar $77 \%$ dalam 5 tahun dan menurunkan tingkat konsumsi beras menjadi $70 \mathrm{~kg} / \mathrm{kapita} / \mathrm{tahun}$. Dengan skenario tersebut, pada 2025 Kalimantan Timur akan surplus beras sebesar 8.620 ton.

\section{Tantangan mewujudkan kemandirian pangan \\ Tantangan terbesar menuju kemandirian} pangan di Kalimantan Timur adalah bagaimana menyiapkan lahan pertanian (padi) untuk memproduksi padi. Saat ini terdapat seluas 5.247 ha sawah beririgasi di Kalimantan Timur dan akan ditingkatkan menjadi 8.864 ha pada 2023 (RPJMD Kaltim, 2018-2023). Sementara itu produktifitas lahan sawah di Kalimantan Timur berada pada kisaran $4 \mathrm{~s} / \mathrm{d} 5$ ton per hektar per tahun (nasional 5,7 ton). Berdasarkan angka-angka tersebut maka kemampuan produksi padi sangat jauh dari jumlah yang dibutuhkan. Berikut adalah perkiraan produksi padi dengan target RPJMD (Tabel 4).

Tabel tersebut menunjukkan kemandirian pangan mustahil diwujudkan seberapapun hebatnya usaha meningkatkan produktifitas lahan per satuan luas (ha). Dengan luasan tersebut, sekalipun Kalimantan Timur mampu melakukan intensifikasi hingga mencapai produktifitas sebagaimana produksi padi tertinggi di dunia, kemandirian itu tidak akan pernah terwujud. Sebagai catatan berikut produktifitas produsen padi dunia. 
Tabel 4. Produksi Padi Berdasarkan RPJMD 2018-2023

\begin{tabular}{|c|c|c|c|c|c|c|}
\hline & \multicolumn{6}{|c|}{ Tahun } \\
\hline & 2018 & 2019 & 2020 & 2021 & 2022 & 2023 \\
\hline $\begin{array}{l}\text { Penambahan Luas Sawah } \\
\text { Beririgasi (ha) }\end{array}$ & - & 700 & 800 & 750 & 700 & 667 \\
\hline Luas Sawah Beririgasi (ha) & 5.247 & 5.947 & 6.747 & 7.497 & 8.197 & 8.864 \\
\hline $\begin{array}{l}\text { Produksi Padi (ton) dengan } \\
\text { kemampuan produksi: } 5 \\
\text { ton/ha }\end{array}$ & 26.235 & 29.735 & 33.735 & 37.485 & 40.985 & 44.320 \\
\hline
\end{tabular}

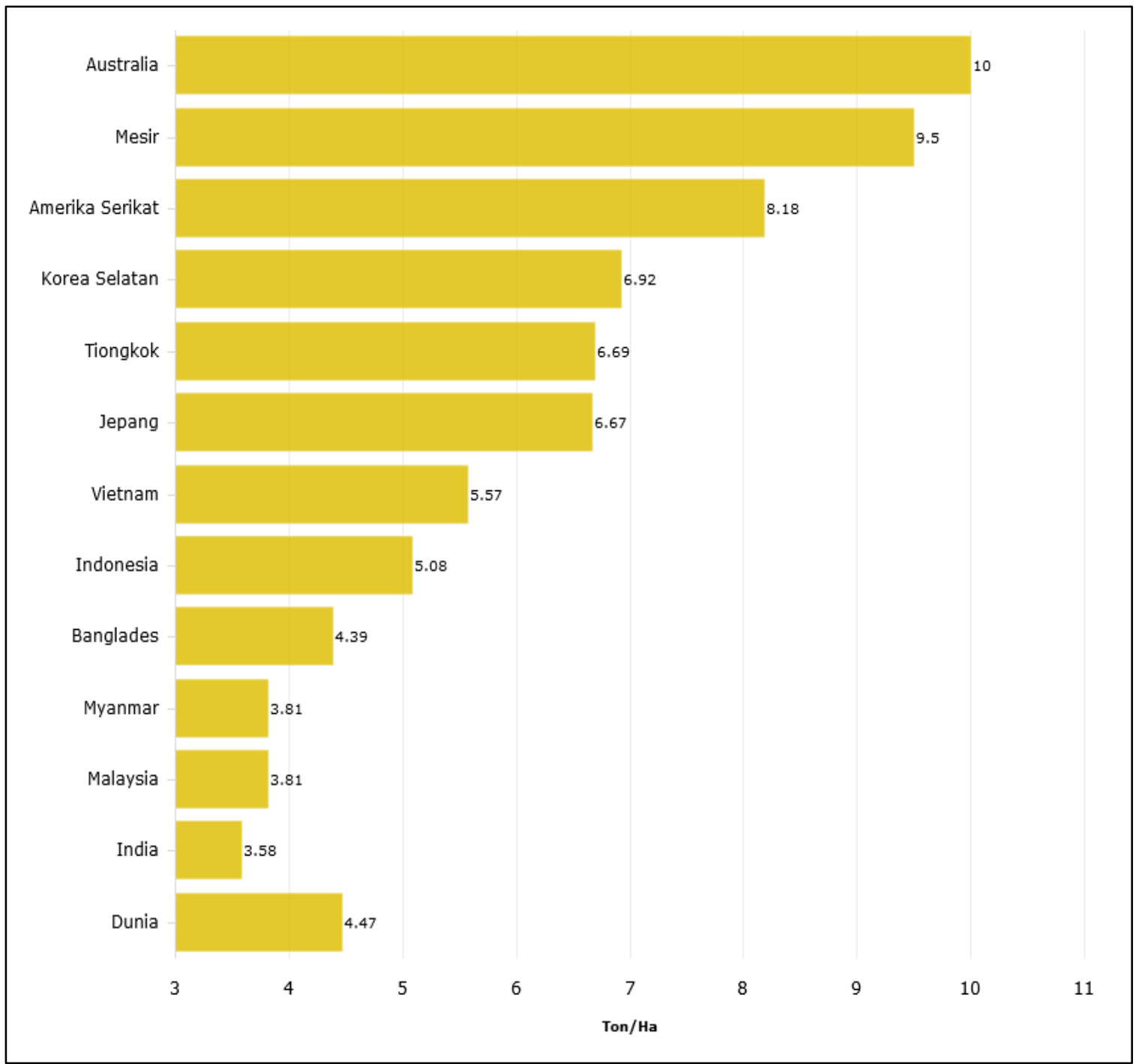

Gambar 2. Produktivitas Produsen Beras Dunia 2010-2014 Sumber: Katadata, 2017 
Data tersebut menunjukkan produktifitas padi tertinggi adalah negara Australia dengan produktifitas 10 ton/ha, sedangkan Indonesia sebesar 5,08 ton/ha. Hal ini mengindikasikan jika Kalimantan Timur mampu meningkatkan produktifitas padi sebagaimana yang dicapai Austalia tidak akan pernah mampu membawa Kalimantan Timur menuju kemandirian pangan, tanpa menambah luas lahan (sawah). Dengan demikian, program ekstensifikasi lahan pertanian harus dilakukan untuk memastikan cita-cita kemandirian pangan bisa diwujudkan.

Tabel 4 diatas menunjukkan bahwa RPJMD hanya menunjukkan data sawah beririgasi sementara potensi sawah non irigasi tidak dimunculkan. Hal ini mengindikasikan bahwa Pemerintah Kalimantan Timur tidak memiliki angka yang pasti terkait potensi sawah non irigasi, padahal fakta menunjukkan bahwa praktek sawah non irigasi banyak dilakukan di masyarakat lokal Kalimantan Timur. Fakta tersebut didukung oleh data BPS Kaltim menunjukkan bahwa produksi padi Kalimantan Timur jauh diatas jumlah produksi sawah irigasi.

Masyarakat lokal Kalimantan Timur lebih dulu mengetahui cara memproduksi padi dari sistem non irigasi yaitu padi ladang dan sawah tadah hujan. Informasi terkait dua hal itu, terutama produksi padi ladang tidak tersedia, baik dari segi luasan maupun produktifitas per satuan luas. Dengan demikian, tantangan utama yang harus diatasi lebih dahulu adalah memastikan lahan untuk produksi padi tersedia, baik sawah beririgasi maupun non irigasi, atau pola produksi padi yang lain. Ketersediaan dan keamanan lahan produksi menjadi syarat utama, karena program-program peningkatan produksi pangan tidak akan memiliki landasan yang kuat tanpa dua hal tersebut.

\section{KESIMPULAN}

Kemandirian pangan bisa dicapai Kalimantan Timur jika dalam 5 tahun ke depan mampu meningkatkan produksi beras sebesar $10 \%$ pertahun atau meningkat sekitar $77 \%$ dalam 5 tahun dan menurunkan tingkat konsumsi beras sampai 70 $\mathrm{kg} / \mathrm{kapita/tahun. \quad Untuk} \mathrm{mendukung}$ terwujudnya cita-cita tersebut maka harus dilakukan upaya memastikan ketersediaan, kesiapan dan keamanan lahan pertanian; meningkatkan produktifitas lahan pertanian dan menurunkan tingkat konsumsi beras per kapita.

\section{DAFTAR PUSTAKA}

Republik Indonesia, 2012. Undang-Undang Nomor 18 Tahun 2012 tentang Pangan. Jakarta: Sekretariat Negara.

Republik Indonesia, 2019. Peraturan Presiden Nomor 22 Tahun 2019 tentang Kebijakan Percepatan Penganekaragaman Konsumsi Pangan Berbasis Sumberdaya Lokal. Jakarta: Sekretariat Negara.

Biro Pusat Statistik Kalimantan Timur, 2019. Kalimantan Timur Dalam Angka 2018. Samarinda.

Biro Pusat Statistik Kalimantan Timur, 2020. Kalimantan Timur Dalam Angka 2020. Samarinda.

Katadata. 2017. Produktivitas Padi Indonesia di Bawah Vietnam. https://databoks. katadata.co.id/datapublish/2017/07/31/pr oduktivitas-padi-indonesia-di-bawahvietnam

Pemerintah Provinsi Kalimantan Timur, 2018. Rencana Pembangunan Jangka Menengah Daerah Kalimantan Timur 2018-2023. Samarinda

Pemerintah Provinsi Kalimantan Timur, 2017. Rencana Aksi Daerah Pangan dan Gizi Kalimantan Timur 2016-2018. Samarinda. 